HANNA PRZYBYSZ

Wydział Filozoficzny

Uniwersytet im. Adama Mickiewicza w Poznaniu
Images

vol. XXVII/no. 36

Poznań 2020

ISSN 1731-45Ox

\title{
Neurobiologia na tropach uniwersalizmu percepcji sztuki. Prawa estetyki V.S. Ramachandrana $i$ W. Hirsteina w kontekście dzieła sztuki filmowej. Studium przypadku: Nadja Michaela Almereydy
}

\begin{abstract}
Przybysz Hanna, Neurobiologia na tropach uniwersalizmu percepcji sztuki. Prawa estetyki V.S. Ramachandrana i W. Hirsteina w kontekście dzieła sztuki filmowej. Studium przypadku: Nadja Michaela Almereydy [Neurobiology in search of the universality in the perception of art. V. S. Ramachandran and W. Hirstein's laws of aesthetic experience in relation to a work of film art. Case study: Michael Almereyda’s Nadja]. “Images” vol. XXVII, no. 36. Poznań 2020. Adam Mickiewicz University Press. Pp. 225-245. ISSN 1731-450X. DOI 10.14746/i.2020.36.15.
\end{abstract}

\begin{abstract}
Vilayanur S. Ramachandran and William Hirstein are the authors of the concept of a work of art understood as an exaggerated stimulus in the creative process. The aim of art, according to them, is (a) to show the essence of something in a perceptually accessible way, and (b) to evoke a strong reaction from the recipient. Scientists say that the aim of art is not to perfectly reproduce reality, but to present the very essence of an object, scene or event by exaggerating its most characteristic features, while ignoring non-essential features. The effect of this treatment is a super stimulus, which is a supernatural stimulus that does not exist in the real world. Researchers have proposed seven universal - evolutionarily and culturally - neurological laws of aesthetic experience in relation to the visual arts (painting and sculpture). I propose to extend the tool apparatus of neuroaesthetics from the area of unimodal arts to a work of film art. It is an interesting tool for research into film aesthetics and masterpieces. In this paper, I will discuss these laws and make a representative analysis of them in a visual case study of Michael Almereyda's film Nadja (1994). The main goal of my work is to show the stricto naturalistic position. Man is not aware that the first stages of cognitive perception have a significant impact on his interest in art, what he pays attention to, and on aesthetic experiences on a sensual, unconscious level. It is an interdisciplinary attempt to provide consistency of research approaches in the humanities with the naturalistic one in the area of natural sciences, which shows that on some levels we are very similar to each other and only in the process of ontogenesis do we acquire individuality - that we are governed by universal laws, not only those related to our individual interests and tastes.
\end{abstract}

KEYWORDS: aesthetics, neuroaesthetics, visual perception, brain, Film Art, Ramachandran, Hirstein, Almereyda, Nadja

Skręciłem na przełaj przez wysoką, zroszoną deszczem trawę i szedłem, zanurzając się coraz głębiej w pustą, jakby leżącą na uboczu świata i niepotrzebną nikomu okolicę. W miarę jak oddalałem się od tamtego świata, czułem się coraz lżejszy i swobodniejszy, coraz bardziej szczęśliwy. Opadały ze mnie po kolei wszystkie niewygodne i krępujące moje ruchy stroje i osłony, które nosiłem na sobie tam, dla obrony przed innymi ludźmi, w celu 
udawania kogoś innego, niż jestem - albo po prostu dla ozdoby. Pozbywałem się też zbędnych myśli i uczuć. [...] Moje zmysły odzyskiwały swoją prawdziwą rolę. Oczy przygotowywały się do widzenia kształtów i kolorów, ruchu i odległości, a także szczegółów, aż do najdrobniejszych. Mój słuch gotów był także do pełnienia swoich obowiązków. Nie potrzebowałem odwoływać się do moich zmysłów, rozkazywać im, prowadzić z nimi dialogów, zasięgać ich rady. Miałem do nich pełne zaufanie, wiedziałem, czułem to, że same, bez mojego wezwania i udziału, będą się ze sobą porozumiewały, wymieniały spostrzeżenia i dokonywały wyboru najlepszej, najkorzystniejszej dla mnie drogi, miejsca i chwili. Nad wodami, do których szedłem, zapadał już mrok, na łąki ścieliła się mgła. Ale ciemne, leżące poziomo chmury uniosły się jeszcze raz tego dnia w górę niby kurtyna, odsłaniając niewiarygodnie jasny i czysty pod spodem błękit i ukazując rąbek słońca, które zatrzymało się na chwilę na granicy nieba i ziemi.

Kornel Filipowicz, Moja kochana, dumna prowincja

Wstęp

[1] Doświadczenie epifenomenologiczne oznacza wstrzymanie lub moment wstrzymania sądu poznawczego i metafizycznego co do przyjętych zasad sposobu istnienia świata, czasowe wzięcie w nawias pewności co do przekonań i założeń. Jest to czerpiący z kartezjanizmu postulat Edmunda Husserla. Oznacza

Na poły epifenomenalne, na poły transcendentne doświadczenie bohatera opowiadania Kornela Filipowicza jest momentem jego zetknięcia z nieodgadnioną i zakrytą przed naszą świadomością zagadką bytu, zawieszoną na granicy nieba i ziemi. W pełnej ufności, bez uzurpacji, poddany prawom natury człowiek oddaje się w pełni pięknu otaczającej rzeczywistości, w oczekiwaniu na uchylenie rąbka tajemnicy Wszechświata i oświecenie[1].

Odkąd ludzie opuścili Platońską jaskinię, percepcja, teoria sztuki i estetyki stanowią niezmiennie jedne $\mathrm{z}$ najważniejszych tematów filozoficznych aktywności człowieka. Myśli Platona, Pseudo-Dionizego Areopagity, Immanuela Kanta, Georga W. Hegla, Martina Heideggera, Friedricha Nietzschego, Jacques'a Derridy, Rudolfa Arnheima, Ernsta Gombricha znalazły w latach dziewięćdziesiątych XX wieku kontynuację w naukach neurobiologicznych. Filozoficzne dociekania na polu nauk o poznaniu dzieł sztuki stały się obiektem zainteresowania badaczy nauk ścisłych, których ukoronowaniem jest neuroestetyka. Współczesne zainteresowanie estetyką ma podłoże w odnowieniu naturalistycznego podejścia $\mathrm{w}$ badaniach nad sztuką oraz pojawieniu się koncepcji „mózgu estetycznego” u twórcy tegoż programu Semira Zekiego. Jednym z głównych zadań, jakie stoją przed badaczami zajmującymi się neuroestetyką, jest znalezienie odpowiedzi na pytanie, w jaki sposób dzieło sztuki wpływa na neurofizjologię człowieka. Głębsza wiedza na temat funkcjonowania ludzkiego mózgu pozwolić może na lepsze zrozumienie zjawiska kontemplacji i zachwytu sztuką, które jest zachowaniem specyficznie ludzkim, niespotykanym wśród innych gatunków. Neuroestetyka zajmuje się identyfikacją oraz analizą pro-

moment, od którego konstruowana jest nowa filozofia, a porzucana stara. Husserl, mówiąc o epoché, czyli redukcji fenomenologicznej, używa znanej metafory brania $w$ nawias. Pojęcie to wydaje się współcześnie stanowić kwintesencję fenomenu doświadczenia dzieła sztuki filmowej. 
cesów percepcyjnych, poznawczych i emocjonalnych, towarzyszących odbiorowi sztuki oraz lokalizowaniem ich aktywności neuronalnej[2], fizjologicznej oraz psychologicznej. Podstawowe jej założenia postulują, że dzieło sztuki jest specyficznym bodźcem aktywizującym i pobudzającym aparat percepcyjno-poznawczy i emocjonalny odbiorcy silniej niż większość obiektów naturalnych oraz że przy jego tworzeniu artysta w sposób nieuświadomiony korzysta $z$ intuicyjnej wiedzy neurobiologicznej dotyczącej działania psychiki i mózgu odbiorcy dzieła sztuki[3]. Badacze zaproponowali siedem uniwersalnych - ewolucyjnie i kulturowo - neurologicznych praw doświadczenia estetycznego w odniesieniu do sztuk wizualnych (malarstwo i rzeźba). Należy jednak pamiętać, że "powstanie neuroestetyki nie oznacza zakwestionowania dotychczasowej wiedzy estetycznej na temat sztuki, ale jej uzupełnienie i rozwinięcie" [4]; zatem badacze z tego obszaru nauki nie podważają dokonań teoretyków sztuki, takich jak Ernst Gombrich czy Rudolf Arnheim, lecz są one dla nich fundamentem dalszego, interaktywnego dialogu interdyscyplinarnego w duchu idei konsiliencji Edwarda O. Wilsona [5].

W mojej pracy proponuję rozszerzenie aparatu narzędziowego neuroestetyki z obszaru sztuk jednomodalnych na dzieło sztuki filmowej. Stanowi on interesujące narzędzie do badań nad estetyką i arcydzielnością filmu. W niniejszej pracy omówię owe prawa oraz dokonam reprezentacyjnej ich analizy w wizualnym studium przypadku filmu Michaela Almereydy Nadja (1994), udowadniając, że nie tylko dzieła wybitnych malarzy czy rzeźbiarzy, ale również dzieło filmowe, a niejednokrotnie pojedynczy jego kadr może pretendować do miana sztuki przez duże „S”.

Głównym celem mojej pracy jest ukazanie stanowiska naturalistycznego w duchu posthumanistycznym[6]. Zaznaczyć należy, że ukazanie to nie radykalne jego zajęcie, lecz przyjęcie postawy holistycznej,

[2] Najpopularniejsze metody pozyskiwania wiedzy na temat reakcji człowieka na bodźce estetyczne to badanie reakcji skórno-galwanicznej, śledzenie ruchu gałek ocznych jako prekursora uwagi (eye-tracking), rejestracja i obserwacja impulsów pojedynczych neuronów w obrębie kory wzrokowej. Neuronauki i kognitywistyka wykorzystują wiele metod neuroobrazowania i badania mózgu oraz poszukiwania struktur mózgowych odpowiedzialnych za procesy poznawcze: tomografie, PET (pozytonowa tomografia emisyjna), MEG (magnetoencefalografia mierzy pole magnetyczne towarzyszące elektrycznej aktywności mózgu) EEG (elektroencefalografia) oraz fMRI (funkcjonalne obrazowanie metodą rezonansu magnetycznego). [3] Zob. P. Baranowski, P. Przybysz, Neuroestetyka wieloznaczności. Percepcja vs. interpretacja $w$ sztuce decentryzmu, Poznań 2018.

[4] P. Przybysz, O uchwytywaniu piękna. Rola deformacji estetycznych $w$ tworzeniu i percepcji dzieła sztuki w ujęciu neuroestetyki, [w:] Mózg i jego umysły. Studia z kognitywistyki i filozofii umysłu, t. 2, red. W. Dziarnowska, A. Klawiter, Poznań 2006, s. 322.

[5] E.O. Wilson stawia hipotezę na rzecz istnienia jedności wszelkiej wiedzy oraz potrzeby poszukiwania konsiliencji świadczącej o tym, że naszym życiem rządzi niewielka liczba fundamentalnych praw przyrody, do których można sprowadzić podstawowe prawa wszystkich dziedzin wiedzy. Zob. E.O. Wilson, Konsiliencja. Jedność wiedzy, przeł. J. Mikos, Poznań 2002.

[6] Mowa konkretnie o posthumanizmie krytycznym, nie o jego nurcie transhumanistycznym. Posthumanizm stricte filozoficzny i odnoszący się do kategorii ludzkiego podmiotu przechodził powolne etapy („kres człowieka” Derridy, „śmierć człowieka” Foucaulta, „śmierć autora” Barthes’a). Ma on swoje źródła w filozofiach Nietzschego, Heideggera i Sartréa w idei człowieka, który jest „projektem”, który „się staje", tworzy w ontogenetycznym rozwoju i doświadczeniu (procesualność). Jest to posthumanizm 
naświetlającej całe spektrum epistemologicznych uwarunkowań homo sapiens, bez pomijania tak ważnej, Darwinowskiej konstatacji. Jest to interdyscyplinarna próba zbliżenia oraz konsiliencji podejść badawczych humanistyki z tym naturalistycznym, z obszaru nauk przyrodniczych, który wskazuje, że na pewnych poziomach jesteśmy do siebie bardzo podobni i dopiero w procesie ontogenezy nabieramy indywidualności że rządzą nami uniwersalne prawa, a nie tylko te związane $\mathrm{z}$ naszymi indywidualnymi zainteresowaniami, potrzebami i gustami - gdzieś tam w głębi, za sprawą ewolucji drzemią w nas zarówno te same nieuświadomione tęsknoty i pragnienia, jak i automatyczne reakcje na bodźce ze świata zewnętrznego, które zwracają naszą uwagę w sposób szczególny. Człowiek bowiem nie jest świadomy, że pierwsze etapy kognitywnej percepcji mają niebagatelny wpływ na jego zainteresowanie sztuką, to, na co zwraca uwagę oraz na doznania estetyczne na poziomie sensualnym.

Neuroestetyka

krytyczny (posthumanizm, postantropocentryzm, postdualizm), który rodzi się w latach czterdziestych i pięćdziesiątych XX wieku, po II wojnie światowej, która zniszczyła człowieka przez duże „C” i jest odwróceniem od wielkich narracji ku małym - kim jest poszczególny człowiek? Następuje decentralizacja i rekalibracja centralnej pozycji człowieka. Współczesna wiedza (ogłoszenie w 2000 roku genomu człowieka) daje nam jednoznaczną wiedzę - w 50\% nasz genotyp jest identyczny z roślinami, $25 \%$ to drożdże, ok. $22,5 \%$ to inne zwierzęta, a nasz ludzki „bagaż” to jedynie kilka procent. Teoria ewolucji jednoznacznie wskazuje, że wszystkie istoty na Ziemi, w tym człowiek, mają wspólnego przodka - bakterię. Chrześcijańska myśl o naszej wyjątkowości i "genialności” na podobieństwo „supermózgu” - Boga - została obalona. Nawet jeśli będziemy się posiłkować uczuciami wyższymi, społecznymi - również. Spadkobiercy Darwina, etologowie, kognitywiści, a w szczególności Franz de Wall (wyszczególnił i potwierdził empirycznie zachowania społeczne małp człekokształtnych: pomaganie, pocieszanie, wzajemność i bezstronność, „małpią sprawiedliwość”, troskę o wspólnotę), wykazali i nadal wykazują brak przepaści pomiędzy gatunkami. Zatem: skoro tylko kilka procent naszego gatunkowego genomu to genom sensu stricto ludzki to jaki promil stanowi o jednostkowej indywidualności?

[7] Zob. S. Zeki, Visual art and the visual brain, „The Woodhull Lecture" 1995.

[8] Zob. V.S. Ramachandran, W. Hirstein, Nauka wobec zagadnienia sztuki. Neurologiczna teoria doświadczenia estetycznego, [w:] Mózg i jego umysty... 
jest wyizolowanie jednego lub więcej obszarów kory wzrokowej, co prowadzi do wzmocnienia percepcji i zogniskowania uwagi na atrybucie pozostawionym w dziele. Przykładem może być sztuka kubizmu, która wyeliminowała głębię (perspektywę) lub szkic izolujący moduł konturu.

Następnie Zeki rozwinął swoje prace na badanie percepcji piękna. Czy jest ono zaklętą tajemnicą zawartą w dziele sztuki? Czy raczej w ludziach, którzy ją percypują? W jaki sposób mózg ludzki widzi piękno? Czy kategorie i pojęcia estetyczne mają swoją reprezentację w ośrodkowym układzie nerwowym, czy są one jedynie indywidualnym rezultatem przetwarzania pojęć i indywidualnych preferencji? Badacz poszukiwał odpowiedzi na owe pytania, przeprowadzając wraz z H. Kawabatą eksperyment empiryczny, który miał na celu identyfikację i zlokalizowanie neuronalnych korelatów piękna (aktywnych neuronów w mózgu) podczas percepcji wizualnych dzieł sztuki[9]. Wyniki uzyskane podczas badania potwierdzają jego tezę o ich istnieniu: podczas oglądania wizualnych dzieł sztuki interpretowanych przez badanych jako piękne największa aktywność neuronów i ich pobudzenie występuje w obszarze przyśrodkowej kory oczodołowej, która między innymi bierze udział w procesie postrzegania, przetwarzania i odczuwania bodźców emocjonalnych (w tym przypadku bodźców nagradzających - układ nagrody[10])[11]. Oglądanie z kolei obrazów uznawanych za brzydkie aktywizuje korę motoryczną, odpowiedzialną za reakcje emocjonalne typu wstręt czy lęk, podczas gdy organizm zwierzęcy reaguje ucieczką w obliczu zagrażającego bodźca. Badanie to, oparte na percepcji sztuki wizualnej, zostało rozszerzone na modalność słuchową. W 2011 roku S. Zeki i T. Ishizu przeprowadzili analogiczny eksperyment dotyczący percepcji muzyki, w który to proces ponownie zaangażowane zostały te same ośrodki w mózgu[12]. Odkrycia te dały podwalinę pod kolejne prace badaczy neuroestetyki - towarzyszących odbiorcy dzieła sztuki emocji estetycznych[13]. Zaznaczyć należy, że temat ten stanowił

[9] Eksperyment przeprowadzony w 2004 roku na dziesięciu badanych (osoby zdrowe; wiek: 20-31 lat). Żadna z nich nie była profesjonalistą, ekspertem ani nie miała doświadczenia $\mathrm{w}$ dziedzinach malarstwa, historii czy teorii sztuki. W ramach pretestu badanym zaprezentowano 300 reprodukcji obrazów wcześniej wybranych subiektywnie przez organizatorów eksperymentu, reprezentujących cztery nurty w malarstwie - martwe natury, pejzaże, malarstwo abstrakcyjne oraz portrety. Zadaniem badanych była klasyfikacja każdego z nich do jednej z trzech kategorii estetycznych: „piękne”, „brzydkie”, „neutralne”. Na podstawie otrzymanych wyników wybrano 192 obrazy, które następnie prezentowano osobom badanym. Ich zadaniem było naciśnięcie odpowiedniego przycisku, wskazującego na to, czy wyświetlany $\mathrm{w}$ danym momencie obraz został przez nie uznany za piękny, brzydki czy neutralny. Badanie polegało na obserwacji aktywności mózgu osoby poddanej badaniu, za pomocą FMRI, w momencie identyfikacji i klasyfikacji konkretnej kategorii. Zob. H. Kawabata, S. Zeki, Neural correlates of beauty, „Journal of Neurophysiology" 2004, 91(4), s. 1699-1705.

[10] Układ nagrody jest częścią „układu limbicznego” (pojęcie umowne) - struktur korowych i podkorowych mózgu, biorących udział w regulacji zachowań oraz stanów emocjonalnych, takich jak uczucie zadowolenia, przyjemność, satysfakcję czy euforię.

[11] Badanie zostało zrekonstruowane i zweryfikowane przez Piotra Francuza, który wykorzystał zasoby kolekcji obrazów w Wilanowie. Zob. P. Francuz, Imagia, Lublin 2013.

[12] Zob. T. Ishizu, S. Zeki, W stronę neurobiologicznej teorii piękna, „Via Mentis” 2012, 1 (1), s. 128.

[13] Teoria Eda Tana emocji estetycznych, czyli takich, które towarzyszą odbiorcy w przeżywaniu dzieła 
obszar zainteresowań już ponad dwieście lat wcześniej. Irlandzki filozof Edmund Burke[14] twierdził, że doznania estetyczne nie są efektem działania osobnych, wyspecjalizowanych mechanizmów biologicznych, lecz powstają dzięki tym samym procesom, co podstawowe, uniwersalne emocje, takie jak miłość czy strach. Uważał on, że pewne obiekty, ludzie czy krajobrazy uznawane są za piękne, ponieważ wywołują takie samo rozluźnienie nerwów jak doznawanie miłości czy czułości.

Inni badacze - Vilayanur S. Ramachandran, profesor neurobiologii, oraz filozof William Hirstein - położyli fundamenty pod przyszłe neuroestetyczne definicje twórcy, dzieła sztuki i odbiorcy, i zaproponowali hipotezę na gruncie ewolucjonizmu, o uniwersalności mechanizmów estetycznych[15]. W 1999 roku wskazali siedem kategorii istotnych dla odbioru dzieł sztuki oraz mechanizmy percepcyjne i ich korelaty w mózgu, biorące udział w procesie jej poznawania i doznawania. W ich koncepcji dzieło sztuki jest artystycznie utworzonym bodźcem poznawczym, który ma obrazować i przekazywać kwintesencję danego zjawiska, a artysta jest świadomym lub nieświadomym neurobiologiem, który intuicyjnie wykorzystuje mechanizmy percepcji swoich odbiorców, aby przekazać ową istotę i wywołać konkretną reakcję u odbiorcy: „Celem sztuki z pewnością nie jest proste zobrazowanie lub przedstawienie realnej rzeczywistości, gdyż to można wykonać bardzo łatwo za pomocą aparatu fotograficznego, ale raczej jej wyolbrzymianie, przekraczanie lub nawet zniekształcanie [...], artysta dąży do wywołania bezpośrednich reakcji emocjonalnych pewnego rodzaju”[16]. Zwrócić należy jednak uwagę, że już pół wieku wcześniej Rudolf Arnheim pisał:

\footnotetext{
Aby stworzyć dzieło sztuki, realizator filmowy musi świadomie wydobyć specyficzne właściwości środka wyrazowego, jakim się posługuje. Powinno to jednak być zrobione w taki sposób, by charakter przedstawionych przedmiotów nie uległ zniekształceniu, lecz został wzmocniony, skondensowany i zinterpretowany[17].
}

sztuki (zarówno wizualnej, muzycznej, jak i filmowej) odnosi się do tezy, że każda pojawiająca się emocja odnosi się do obiektu, który tę emocję wywołał w tym przypadku - do dzieła sztuki. Tan uważa, że w wyniku percepcji sztuki wizualnej powstają między innymi emocje skategoryzowane przez niego jako „emocje typu A”, które odnoszą się bezpośrednio do artefaktów (ang. artifact) i ich własności formalnych. Do emocji tych zalicza podziw dla kunsztu twórcy (lub dezaprobatę) - na przykład doskonale oddanych kolorów czy detali, zastosowanej kompozycji, użytego rodzaju światła - oraz przyjemność estetyczną związaną z tymże zachwytem. Drugą kategorię, związaną z niematerialnymi, mentalnymi doznaniami, towarzyszącymi obcowaniu ze sztuką Tan nazywa „emocjami typu R" (ang. represented world). Powstają one w wyniku odpowiedzi na przetworzoną w umyśle sytuację przedstawioną przez artystę - pojawiające się w tym kontekście emocje dzieli na empatyczne oraz nieempatyczne: (i) emocje empatyczne pojawiają się, gdy obserwator wczuwa się $\mathrm{w}$ rolę przedstawionej postaci oraz „współuczestniczy w wydarzeniach” i współodczuwa z przedstawionym bohaterem, (ii) emocje nieempatyczne powstają w wyniku niezaangażowanej postawy - z punktu widzenia obiektywnego obserwatora. Zob. E. Tan, Emocje a sztuka i humanistyka, [w:] Psychologia emocji, red. M. Lewis, J.M. Haviland-Jones, Gdańsk 2005.

[14] Zob. E. Burke, Philosophical Enquiry into the Origin of Our Ideas of the Sublime and the Beautiful. Harmondworth 1998.

[15] Zob. V.S. Ramachandran, W. Hirstein, op.cit., s. 327 .

[16] Ibidem, s. 330.

[17] R. Arnheim, Film jako sztuka, przeł. W. Wertenstein, Warszawa 1961, s. 30-31. 
Celem sztuki i filmu (jako jej syntezy) według Arnheima jest zahamowanie procesu przedstawiania rzeczywistości przy równoczesnej intensyfikacji procesu rozwijania ekspresji (sic! - por. Ramachandran i Hirstein) [18].

Jak widać - parabolicznie - kontynuując tę prekursorską myśl Arnheima, który jako pierwszy udowodnił naukowo, na podstawie paradygmatu teorii widzenia i psychologii, że film może być sztuką - badacze wykazali, że zasady te i prawa są uniwersalne, jednakże odnosząc się jedynie do malarstwa, rysunku i rzeźby - sztuk jednomodalnych. W poniższej analizie pojedynczego dzieła sztuki filmowej - Nadji (1994) Michaela Almereydy, postaram się wykazać w duchu Arnheimowskim, że prawa te rządzą również sztukami złożonymi, takimi jak na przykład właśnie film.

Opierając się na postulacie zahamowania procesu przedstawiania rzeczywistości przy równoczesnej intensyfikacji procesu rozwijania ekspresji, Ramachandran i Hirstein stali się autorami koncepcji dzieła sztuki rozumianego jako bodziec wyolbrzymiony w procesie twórczym. „Celem sztuki jest, według nich, (a) ukazanie w dostępny percepcyjnie sposób istoty czegoś, oraz (b) wywołanie silnej reakcji

\section{Prawa estetyki - Vilayanur \\ S. Ramachandran i William Hirstein. Studium przypadku: Nadja (1994) Michaela Almereydy}

[18] Już w 1933 roku Rudolf Arnheim, doktor psychologii i filozofii Uniwersytetu Harvarda, w krótkim dziele Film jako sztuka przedstawił teorię opierającą się na psychologii postaci i widzeniu jako chwytaniu struktur wzorów zgodnie z zasadami prostoty, typowości, regularności i równowagi w celu uogólniania informacji. W Sztuce i percepcji wzrokowej przedstawił zagadnienia równowagi, kształtu, formy, rozwoju, przestrzeni, światła, koloru, ruchu, dynamiki i ekspresji. O potrzebie zmiany tradycyjnego „patrzenia” na sztukę poprzez formę świadczy jego postulat - że należy: „, [...] porzucić [...] pretensjonalną i mętną gadaninę, żonglerkę frazesami i suchymi pojęciami estetycznymi, pseudonaukową dekorację, [...] pedantyczne bawienie się $\mathrm{w}$ drobiazgi, czarujące epigramy wreszcie" (R. Arnheim, Sztuka i percepcja wzrokowa. Psychologia twórczego oka, przeł. J. Mach, Gdańsk 2004, s. 16). Arnheim, wysnuł hipotezę, że film, pomimo mechanicznej rejestracji, jest dziedziną sztuki. Jego zdaniem jest sztuką reprodukcji, która przedstawia rzeczywistość, ale przekracza ją za pomocą braków - dzięki którym oddala się od niej, tym samym spełniając funkcję dzieła sztuki. Wyróżnia sześć braków, które stanowią o artyzmie filmu (za: A. Helman, J. Ostaszewski, Historia myśli filmowej, Gdańsk 2007): 1) rzutowanie brył na płaszczyznę jeden punkt widzenia kamery implikuje rzut obiektu na płaszczyznę, tym samym reprodukcja przestaje być mechanicznym procesem, gdyż wymaga wyczucia natury obiektu, wymuszając rzuty niereprezentatywne; 2) redukcja głębi - brak stałości wielkości, kształtu; obiekty nie są postrzegane w naturalnych wymiarach i proporcjach, lecz perspektywicznym zniekształceniu, w przeciwieństwie do postrzegania rzeczywistości, gdy umysł kompensuje różnice. Arnheim pisze, że: „wrażenie filmowe nie jest ani absolutnie dwuwymiarowe, ani absolutnie trójwymiarowe, jest czymś pośrednim" (Arnheim, Film jako sztuka..., s. 14); 3) oświetlenie i brak koloru - film czarno-biały nie odzwierciedla rzeczywistości, a możliwości oświetlenia dają nieograniczone rozwiązania w zakresie rodzaju, punktu rzutowania i funkcji, jakie ma ono spełniać; 4) granice obrazu - są źródłem możliwości artystycznych. Ramy kadru i nieskończoność możliwych ujęć i sposobów ukazywania materiału nie są odpowiednikiem naszego postrzegania rzeczywistości; 5) brak ciągłości czasowo-przestrzennych - w codziennym życiu nie doświadczamy skoków czasoprzestrzennych, w przeciwieństwie do filmu, w którym za pomocą montażu dzieje się to nieustannie. „Film jest zawsze, w jednej i tej samej chwili, płaską pocztówkową fotografią i sceną żywej akcji" (ibidem, s. 24); 6) brak pozawizualnego świata zmysłów - film sugeruje doznania pozawizualne, takie jak dotyk, zapach, równowagę jedynie za pomocą modalności wzrokowej. Arnheim odwołuje się do teorii częściowego złudzenia, dzięki któremu obiekty i wydarzenia filmowe postrzegamy równocześnie 
w odbiorcy"[19]. Naukowcy twierdzą, że celem sztuki nie jest idealne odwzorowanie rzeczywistości, lecz przedstawienie samej istoty danego obiektu, sceny czy wydarzenia poprzez wyolbrzymienie jego najbardziej charakterystycznych cech, przy jednoczesnym pominięciu cech nieistotnych. Efektem tego zabiegu jest superbodziec, będący ponadnaturalnym obiektem odniesienia do tego, co artysta zamierzał przekazać i zobrazować. Badacze zaproponowali siedem neurologicznych praw doświadczenia estetycznego:

\section{Prawo przesunięcia szczytowego}

Badacze przywołują sanskrycki termin rasa, który oznacza „istotę” czegoś. Uchwycenie przez artystę owej „istoty”, kwintesencji danego obiektu, następnie umniejszenie albo redukcja nieistotnych, odwracających uwagę elementów i wyostrzenie znaczących cech w sposób niewystępujący w naturze, tworzy superbodziec (bodziec ponadnormalny). Jednym z głównych argumentów, jak i funkcjonalnych przykładów tej tezy ma być efekt przesunięcia szczytowego, który scharakteryzować można jako tendencję do silniejszego reagowania na bodziec odbiegający charakterem od tego, do którego jesteśmy przyzwyczajeni (nasuwa się w tym miejscu zagadnienie habituacji[20] i próba jej zniwelowania przez artystę w celu zogniskowania uwagi na obiekcie przedstawionym i jak najdłuższego utrzymania zainteresowania odbiorcy). Zasada przesunięcia szczytowego jest ilustrowana przez badaczy rzeźbą hinduską, która, uwydatniając kobiece, krągłe kształty i roztańczoną w zmysłowej pozie - Kamienna nimfe - wywołuje niecodzienne doznania. Przedstawiona kobieta zwraca uwagę wyjątkowymi proporcjami i kształtami, które zostały wyolbrzymione - piersi i biodra są wybujałe, wyjątkowo okrągłe i duże, a talia niezwykle wąska. Również jej poza (tribhanga - w sanskrycie „potrójne zgięcie") i wygięcie lędźwiowe kusi i ukazuje wyolbrzymione, typowo kobiece ułożenie ciała, niemożliwe do osiągnięcia z przyczyn budowy kośćca, przez mężczyzn (wyolbrzymienie cech kobiecych - eliminacja męskich). Zdaniem Ramachandrana i Hirsteina każdy artysta w sposób świadomy lub nieświadomy chce nie tylko uchwycić w swoim dziele istotę danego zjawiska, ale także ją uwypuklić - wyolbrzymić i zintensyfikować w sposób odbiegający od naturalnego postrzegania obiektów w rzeczywistości, w celu wzmożonej alokacji uwagi. Aktywo-

jako żywe i rzeczywiste oraz jako występujące jedynie w świecie naszej wyobraźni (A. Helman, J. Ostaszewski, op.cit., s. 102-105). Zob. R. Arnheim, Film jako sztuka... oraz idem, Sztuka i percepcja wzrokowa... [19] P. Markiewicz, P. Przybysz, Neuroestetyka. Przegląd zagadnień i kierunków badań, [w:] Na ścieżkach neuronauk, red. P. Francuz, Lublin, 2010, s. 109. [20] Habituacja to jedna $\mathrm{z}$ form asocjacyjnego uczenia się. Rodzajów habituacji jest wiele - ogólnie proces ten polega na stopniowym zanikaniu procesów percepcyjnych i reakcji na powtarzający się, znany, niezagrażający na przykład przetrwaniu i poczuciu bezpieczeństwa bodziec, jeśli nie niesie żadnych istotnych zmian. Standardowym przykładem może być brak zainteresowania opatrzonym krajobrazem wokół domu, i niezauważanie powolnych, nieznacznych zmian, dopóki nie przewróci się na przykład drzewo. Jeszcze celniejszym przykładem jest niezauważanie oznak starzenia się u osób, z którymi mieszkamy lub widzimy się codziennie. 
wane w wyniku owego zogniskowania zainteresowania mechanizmy neurofizjologiczne, pobudzane i wzmacniane są jeszcze silniej. Prawo to w przypadku analizowanego w tej pracy filmu Michaela Almereydy Nadja, realizowane jest na wielu płaszczyznach obrazu (zgodnych z koncepcją mózgu wizualnego S. Zekiego).

\section{Przestrzeń konturu/ksztaltu}

W prezentowanych na ilustracji 1, 2 kadrach zasada przesunięcia szczytowego konturu zrealizowana jest dwojako. Na ilustracji pierwszej sylwetki i obiekty planu pierwszego są całkowicie zaciemnione poprzez zastosowanie światła kontrowego, uwydatniając jedynie ich kształty bez szczegółów (faktur), przenosząc widza na poziomie mentalnym do świata Platońskiej jaskini cieni. Przykład drugi to wysoka pikselizacja obrazu, która rozmywa kontury nie tylko sylwetek, ale każdego szczegółu zawartego w kadrze. W obu przypadkach mamy do czynienia z obrazem ponadnaturalnym, pozostającym poza doświadczeniem dnia codziennego.

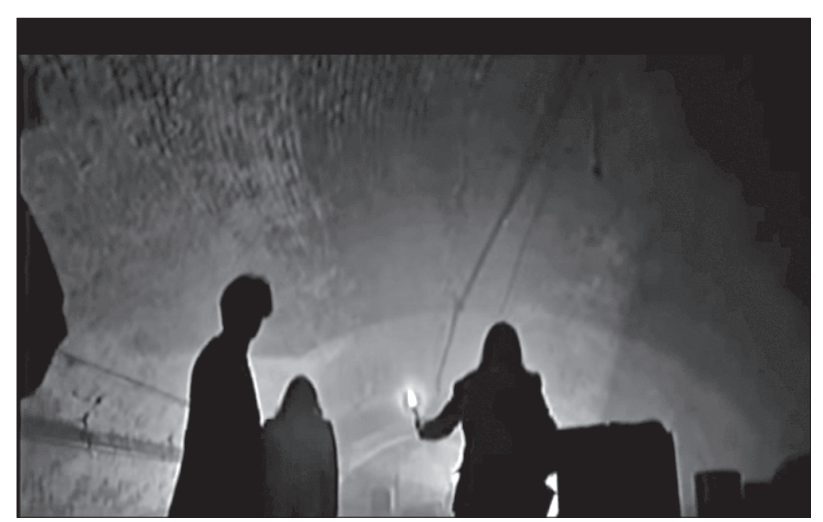

\section{Przestrzeń koloru}

Zasada przesunięcia szczytowego w przestrzeni koloru spełnia ideę bodźca ponadnaturalnego w sposób iście sztandarowy i w zasadzie nadrzędny dla całego dzieła - ideę bodźca całkowicie nieobecnego $\mathrm{w}$ codziennym doświadczeniu percypowanej rzeczywistości. Film jako dzieło czarno-białe redukuje kolor i pozostawia warstwę achromatyczną, nie angażuje zatem neuronalnych ośrodków przetwarzania koloru, a dodatkowo na wyższych poziomach poznania uruchamia obszary kory nowej w mózgu, odpowiedzialne za przetwarzanie semantyczne i pojęciowe (symbolika czerni i bieli).

\section{Przestrzeń faktury}

W przypadku faktury prezentowane na ilustracji 3 i 4 kadry na zasadzie opozycji - prezentują doskonałą, „marmurową” gładkość i świetlistość twarzy głównej bohaterki, która stanowi opozycję do zniszczonej, pełnej blizn, chropowatej skóry innego bohatera filmu. Zabieg ten na planie symbolicznym odzwierciedla stan ciała i ducha tejże pary. Bliźniacze rodzeństwo jest potomstwem Draculi - ona kul-
Il. 1, 2. Kadry z filmu Nad$j a$, reż. Michael Almereyda, 1994 rok 
tywuje „krwiopijczość” i nieśmiertelność ojca, zachowując doskonałość ciała; on - sprzeniewierzył się dziedzictwu i ulega bolesnej destrukcji biologicznej. Co ciekawe - kompozycyjnie kadry te również okazują się „bliźniacze” i tworzą paralelę (łóżko, kąt ekspozycji twarzy, stan snu etc.), ponieważ odnoszą się do dwóch różnych scen filmu.
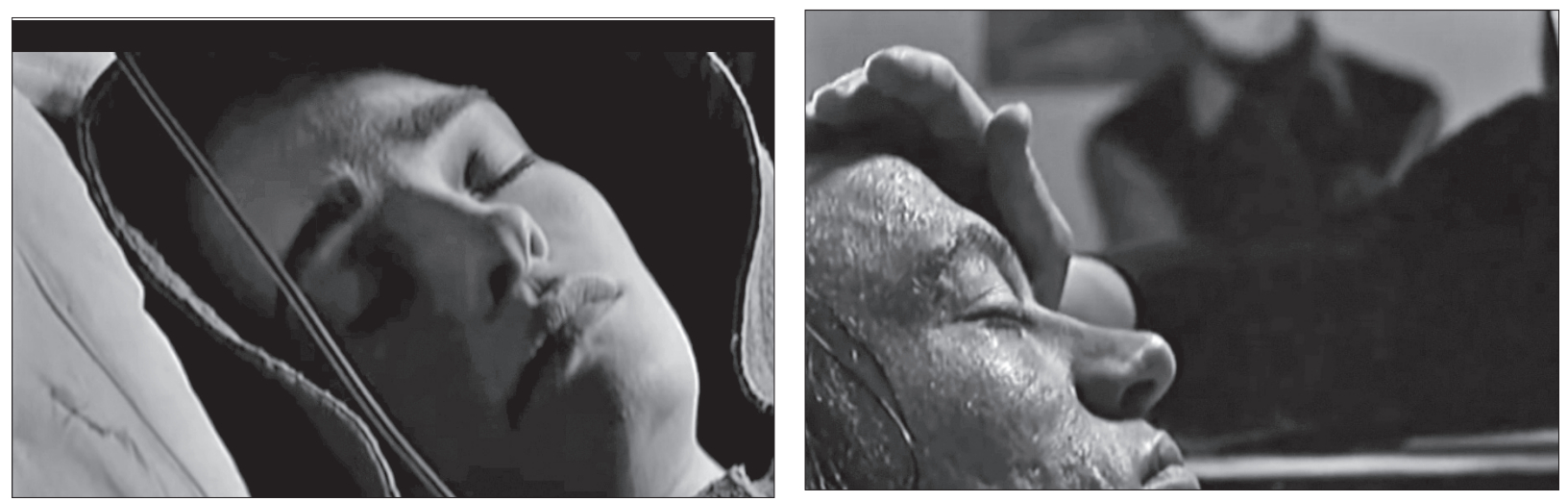

Il. 3, 4. Kadry z filmu Nadja, reż. Michael Almereyda, 1994 rok
Przestrzeń głębi. Kwestie głębi i perspektywy sceny wizualnej również realizowane w filmie są dwubiegunowo. Na przykładzie z ilustracji 5 mamy do czynienia z płaskim obrazem, który to zabieg został osiągnięty poprzez rejestrację odbić ulicznych świateł oraz wieżowca w oddali w szybach szklanego budynku na planie pierwszym; obraz tworzy jednowymiarową, ekspresjonistyczną mozaikę, dostępną co prawda w świecie rzeczywistym, ale tylko uważnym i refleksyjnie zorientowanym obserwatorom dnia codziennego.
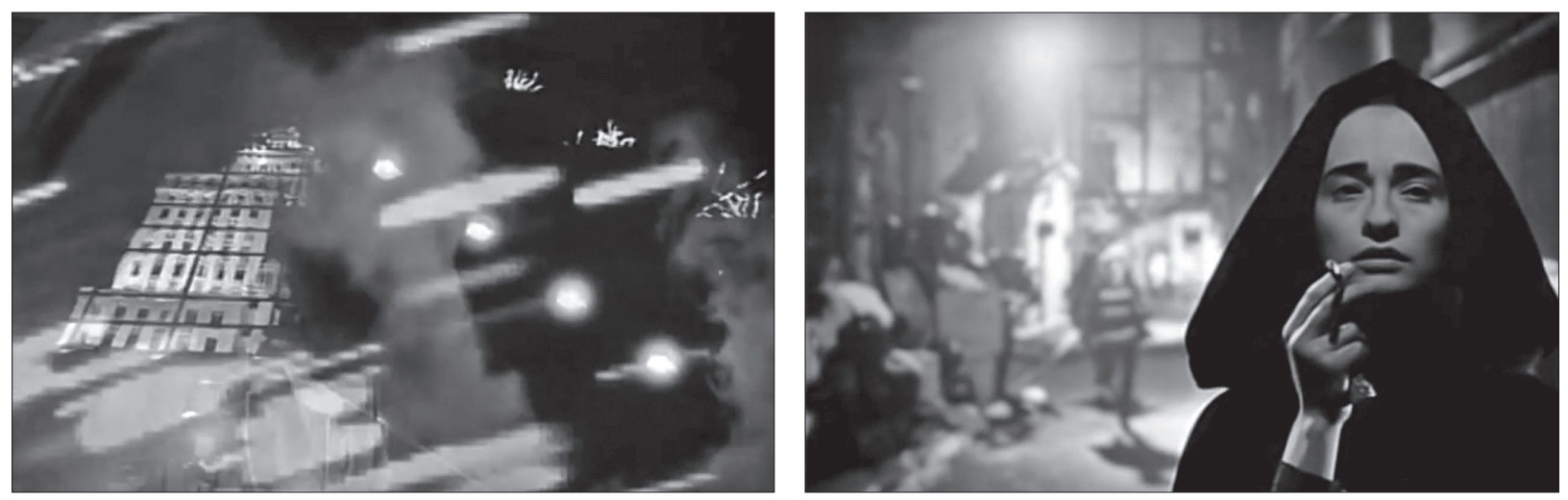

Il. 5, 6. Kadry z filmu Nadja, reż. Michael Almereyda, 1994 rok
Na ilustracji drugiej sytuacja się odwraca. Głębia obrazu znów osiągnęła maksymalne „przesunięcie” zarówno na poziomie kontrastu, perspektywy, światła, jak i ruchu - ujęcie kręcone jest w trybie slow-motion. Zaczerniona, ale ostro zarysowana bohaterka na planie pierwszym pozostawia za sobą ulicę miasta i biegnących za nią bohaterów w pogłębiającej świetlistości i rozmyciu, zaś apogeum „nieskończonej”, tunelowej przestrzeni obraz osiąga w oślepiającym źródle światła w oddali. 


\section{Przestrzeń światła}

Owa kontrastowość światła - od mrocznej otchłani do iluminacji - osiąga swój szczyt maksymalnego przesunięcia w scenach zaprezentowanych na ilustracjach 7 i 8. Przykład drugi dodatkowo urzeczywistnia poprzez swoje ekstremalne, aż do zaniku obrazu, rozświetlenie promieniami słońca, naturę przedstawionej kobiety - jest ona matką wampirycznego rodzeństwa, czystą wewnętrznie i cnotliwą ukochaną bezlitosnego hrabiego Draculi, która, umierając w połogu, zabrała ze sobą owe światło i pozostawiła rodzinę we władaniu ciemnej stronie natury ludzkiego ducha.

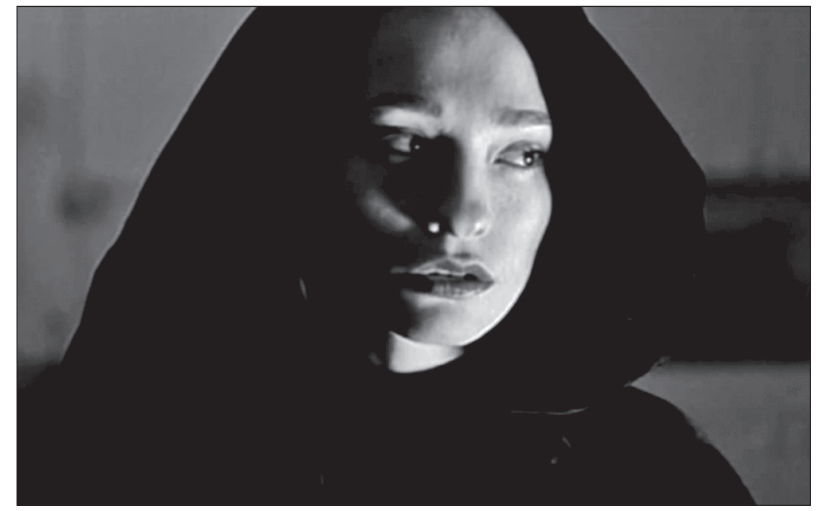

\section{Przestrzeń ruchu}

Przesunięcie szczytowe w obszarze ruchu ponownie realizowane jest na dwa sposoby. Kadr pierwszy to stroboskopowe szaleństwo klubu nocnego, gdzie w naprzemiennych błyskach czerni i światła, w poklatkowym tempie wyświetla nam się tańcząca bohaterka. Jej ruchy nakładają się na siebie i w efekcie w kadrze widzimy jej podbródek, profil popiersia oraz pełną ekspresji dłoń równocześnie. Scenę intensyfikuje fakt, że jest ona zmiksowana w kilkusekundowych odstępach czasowych ze sceną drugą, w której ta sama bohaterka, płacząc, idzie samotnie, zagubiona, powoli, ulicą (zob. il. 16).

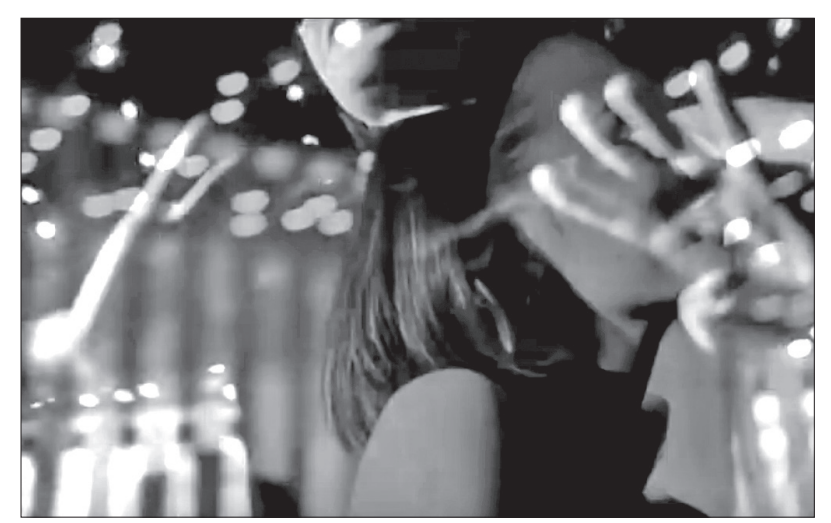

Kadr przedstawiony na ilustracji 10 to samotny spacer Nadji ulicami miasta w trybie slow-motion, dodatkowo spotęgowany akom-
Il. 7, 8. Kadry z filmu Nadja, reż. Michael Almereyda, 1994 rok

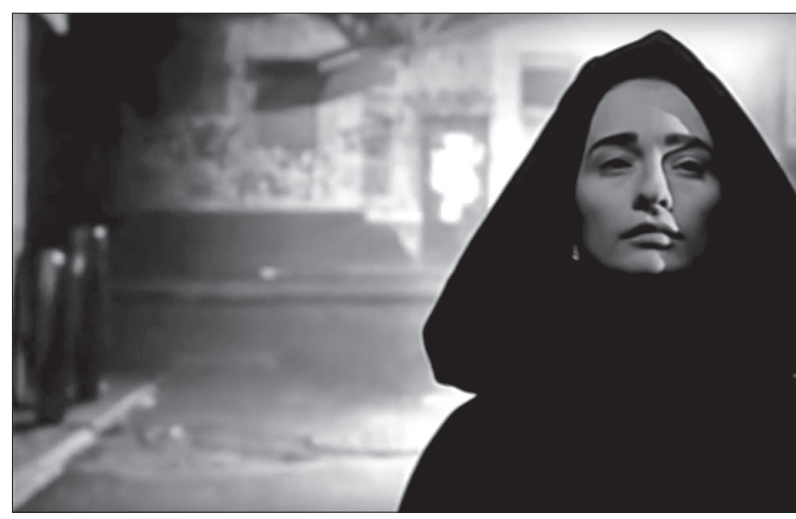

Il. 9, 10. Kadry z filmu Nadja, reż. Michael Almereyda, 1994 rok 
paniamentem transowej, przeszywającej zarówno przestrzeń kadru, jak i odbiorcę muzyki (będącej również rodzajem ruchu) zespołu Portishead[21]. Bohaterka nie idzie - ona „sunie” w hipnotycznym transie, jakby unosiła się nad powierzchnią ulicy. Obie sceny charakteryzuje również opozycja stanów emocjonalnych - ze sceny pierwszej epatuje skrajna radość granicząca $\mathrm{z}$ ekstazą, z drugiej - przejmująca, melancholijna pustka i apatia.

\section{Prawo grupowania}

Drugim prawem jest „grupowanie” elementów sceny. V.S. Ramachandran i W. Hirstein nawiązują do odkrycia tegoż prawa przez psy-

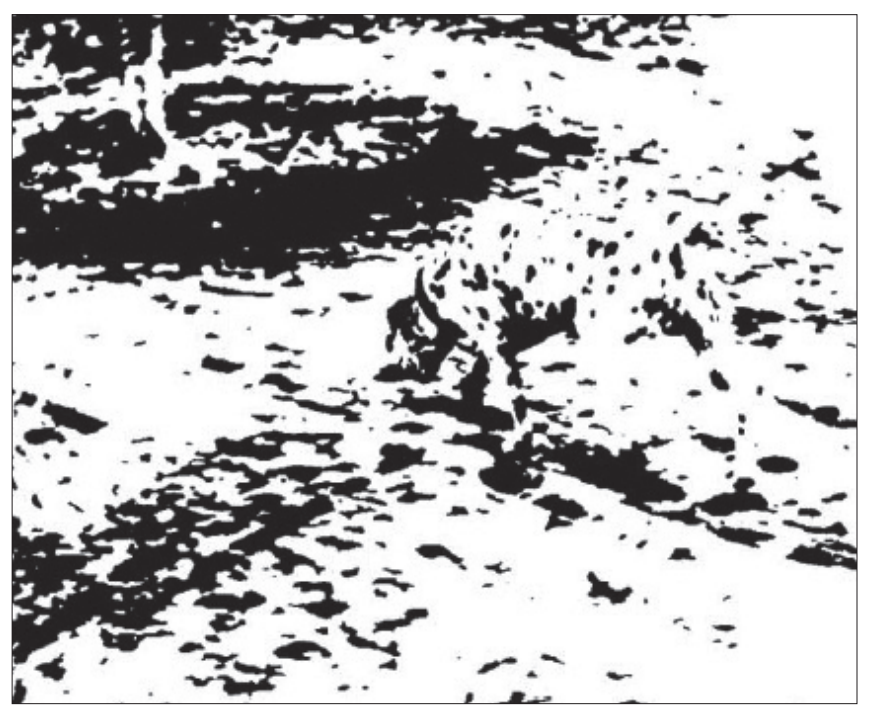

Il. 11. Początkowo widzimy jedynie mieszaninę plam, lecz gdy spostrzeżemy dalmatyńczyka, plamy grupują się, co samo w sobie jest przyjemnym efektem, spowodowanym zapewne przez aktywację systemu limbicznego za pośrednictwem płata skroniowego kory mózgu tychże plam). chologów postaci Gestalt z przełomu XIX i XX[22] wieku i rozumieją je „jako jedną z głównych funkcji pierwotnego widzenia [...], którą jest wykrycie i zarysowanie obiektów w polu widzenia" [23] oraz wyodrębnienie i odróżnienie tychże obiektów od tła. Badacze wysnuwają wniosek, że skorelowanie poszczególnych obiektów wizualnych w taki sposób, aby stały się zrozumiałe, musi być korzystne dla organizmu po to, aby dostarczać bodźca do odkrywania tego typu korelacji. Korzyść ta miałaby wiązać się z przyjemnością odczuwaną z „odkrycia” tejże korelacji i reakcją „Aha!”. Źródłem ma być impuls płynący z układu limbicznego, dzięki któremu mózg z przyjemnością daje się zwodzić i czerpie satysfakcję z tworzenia owych grup[24]. Badacze wskazują na potencjalnie nieskończoną ilość możliwych grupowań w przypadku dalmatyńczyka oraz prawidłowość polegającą na mentalnej niemożności „opuszczenia” połączonej uprzednio grupy plam. Raz zidentyfikowany węszący dalmatyńczyk na trawniku (il. 11) pozostaje „W umyśle” i przy kolejnej próbie system wzrokowy natychmiast "uchwytuje" kształt i głębię, bez potrzeby ponownej analizy (grupowania

Zdaniem Ramachandrana grupowanie wyewaluowało w celu wykrywania kamuflażu[25] i identyfikowania obiektów znajdujących się

[21] „Stylistyczną odrębność zapewniły Portishead osobowość i niepodważalna charyzma Beth Gibbons. Już w otwierającym płytę utworze Mysterons otrzymujemy pierwszą próbkę jej umiejętności budowania wyjątkowego nastroju. Zresztą dotyczy to całego albumu. Beth jednym razem delikatnie skrada się do naszych uszu, innym zaś przyspiesza nieco i zwiększa natężenie głosu; zawsze jednak hipnotyzuje słuchacza jakąś niewytłumaczalną tajemnicą”. Za: <https://www. substanceonly.net/portishead > dostęp: 16.09.2020.
[22] Kategorie Gestalt to kategorie: domknięcia, figury-tła, podobieństwa, bliskości, symetrii, emergencji, reifikacji, multistabilności, niezmienniczości; są to zasady ujmowania zjawisk w całości i izomorfizmu psychofizycznego.

[23] V.S. Ramachandran, W. Hirstein, op.cit., s. 341.

[24] Grupowanie możliwe jest dzięki ośrodkom w mózgu odpowiedzialnym za percepcję wzrokową konturu, koloru, kształtu i ruchu.

[25] Służącemu przetrwaniu: zarówno ochronie, jak i udanym „polowaniom” (np. kamuflaż wojenny). 
w „zagraconej” scenie, a każdorazowy „sukces” i rozwiązanie zagadki zostają nagrodzone zadowoleniem perceptora[26].

Obie zaprezentowane na ilustracjach 12 i 13 „zagracone sceny” wymagają wyostrzonego zmysłu wzroku i uwagi oraz namysłu i uporządkowania, niczym puzzle, ich poszczególnych składowych w zrozumiałą dla widza całość.

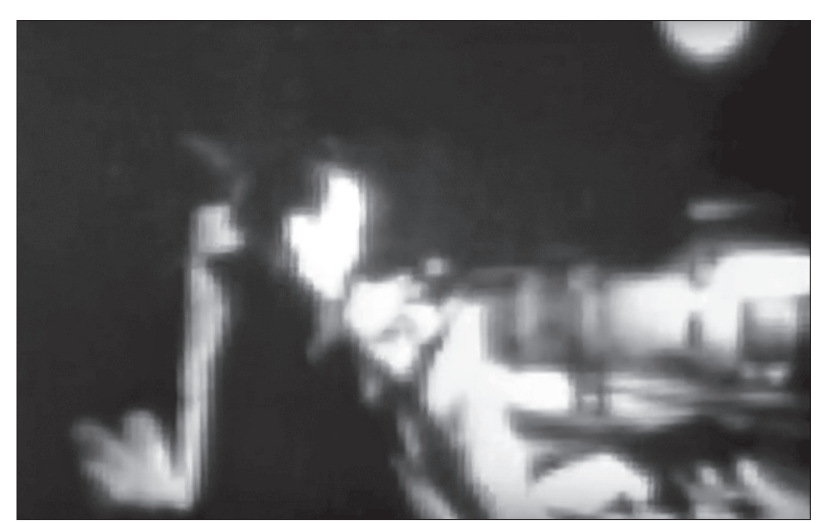

Na ilustracji 12 widzimy ugodzonego drewnianym kołkiem, słaniającego się człowieka. Jednak znowu zastosowana pikselizacja obrazu, skrajny kontrast świateł i brak szczegółów sprawiają, że na planie pojawiają się jedynie białe „plamy”. Ich kategoryzacja, uporządkowanie i rozpoznanie wymagają długiego procesu percepcyjnego i stanowią niecodzienne zadanie kognitywne dla odbiorcy. Scena druga rozgrywa się we wnętrzu mieszkania, w którym bohaterki rozpalają „zimne ognie”. Ich rozbłyski i naprzemienne zaciemnienie i niedoświetlenie sylwetek wprowadzają grę świateł oraz brak spójnego obrazu (ponownie przesunięcie szczytowe w przestrzeni światła). Dodatkowo - w tejże scenie mamy do czynienia albo z krajobrazem onirycznego spowolnienia, albo efektu przyspieszonego migotania (przesunięcie szczytowe przestrzeni ruchu omówione wyżej).

\section{Izolowanie pojedynczego modułu}

Zasada ta mówi o selektywności systemu uwagowego: jesteśmy w stanie skupiać naszą uwagę na jednej rzeczy w danym czasie[27]. Ponieważ nasza uwaga nie jest rozpraszana przez dodatkowe informacje, w danej chwili nieistotne, często proste szkice wydają nam się atrakcyjniejsze niż realistyczne fotografie. Badacze twierdzą, że odizolowanie pojedynczej kategorii percepcyjnej (na przykład kształtu, głębi) pozwala na „izolowanie pojedynczej modalności wizualnej, zanim nastąpi wzmocnienie sygnału w ramach innych modalności”, a co za tym idzie, na efektywniejsze nakierowanie uwagi na jedno źródło informacji, umożliwiając w ten sposób zauważenie wyolbrzymienia
[26] V.S. Ramachandran, Neuronauka o podstawach człowieczeństwa. O czym mówi mózg, przeł. A. Binder, M. Binder, E. Józefowicz, Warszawa 2012, s. 222.
[27] Zob. T. Maruszewski, Psychologia poznania, Gdańsk 2001, s. 9.
Il. 12, 13. Kadry z filmu Nadja, reż. Michael Almereyda, 1994 rok 
użytego przez artystę[28]. Przykłady ilustrujące to karykatura oraz szkic. W tym kontekście wyjątkowo trafny jest aforyzm „im mniej, tym lepiej w sztuce”. Oznacza to, że jeśli do rozpoznania przedstawienia wystarczy posłużenie się jedną tylko kategorią, taką jak kolor czy kształt, to należy ową redukcję wprowadzić, ponieważ „nadmiarowe” informacje "przeszkadzają jedynie ograniczonym zasobom koncentracji uwagi w zdefiniowaniu atrybutów danego obiektu"[29] oraz rozpoznaniu i docenieniu zamysłu artystycznego twórcy.

Dynamika percepcji polega na tym, że jeden stabilny percept (postrzegany bodziec) automatycznie wyklucza pozostałe. Zachodzące na siebie wzorce neuronalnej aktywności i obwody neuronalne w mózgu nieustannie rywalizują o ograniczone zasoby uwagi. Dlatego kiedy patrzymy na barwną fotografię, uwaga jest rozpraszana przez nadmiar barw, faktur i innych szczegółów obrazu. Szkic tego samego obiektu pozwala skierować całą uwagę na kontur, tam, gdzie jest istotna informacja (czyli kształt $\rightarrow$ identyfikacja obiektu). [...] jeśli artysta chce przywołać rasa barwy przez wprowadzenie przesunięcia szczytowego i ponadnormalne bodźce w przestrzeni koloru, to powinien zminimalizować kontury [...]; przez rozmazywanie krawędzi albo zupełne ich pomijanie[30].

Odizolowanie pojedynczej kategorii percepcyjnej pozwala zauważyć wyolbrzymienie użyte przez artystę. W przypadku analizowanego przeze mnie filmu izolowanie pojedynczego modułu sprowadza się do wspomnianego wyżej zredukowania palety barw do odcieni szarości, a tym samym „odciążenia” obszaru w mózgu odpowiedzialnego za percepcję koloru. Jednak cały film realizuje tenże postulat na poziomie innych modułów: na poniższej ilustracji - izoluje głębię, faktury oraz oczywiście kolor, pozostawiając jedynie światło i kontur; kadr drugi to jedynie płaska gra konturów.
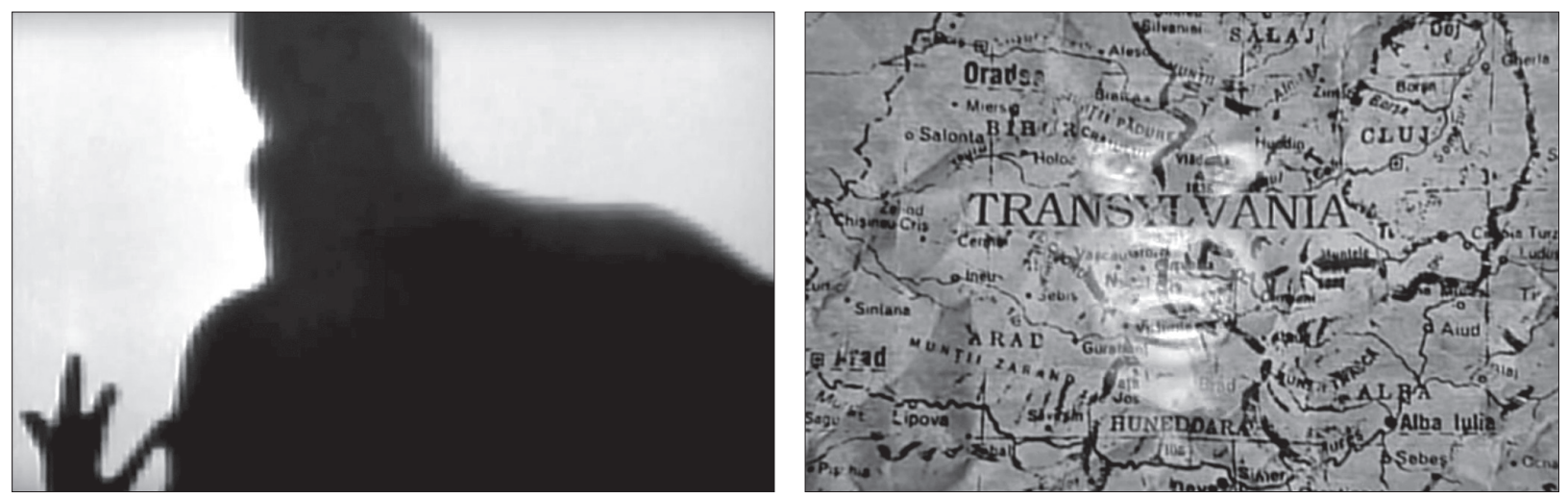

Il. 14, 15. Kadry z filmu Nadja, reż. Michael Almereyda, 1994 rok

\section{Kontrast}

Kolejnym prawem jest prawo kontrastu. Kontrast w języku nauki to znacząca różnica jakiejś własności - jasności, barwy, światła, głębi ostrości a nawet faktury - między dwoma przylegającymi homogenicznymi częściami przestrzeni[31]. Badacze jednoznacznie udowadniają, że

[28] V.S. Ramachandran, W. Hirstein, op.cit., s. 346. [29] Ibidem s. 347.
[30] V.S. Ramachandran, op.cit., s. 241.

[31] Ibidem, s. 238. 
wydobywanie kontrastu jest fundamentalnym elementem w procesie percepcji wzrokowej oraz wywołuje przyjemne doznania, ponieważ w miejscach, gdzie zachodzą zmiany, zawartych jest najwięcej informacji dla aparatu wzrokowego. Autorzy rozszerzają nieco tradycyjne pojęcie kontrastu, nie ograniczając go tylko do skokowych zmian luminancji. Mówią o kontrastach występujących w różnych wymiarach: kształtu, koloru, tekstury, wielkości, ruchu czy nawet kontraście delikatnego, nagiego ciała kobiety z ciężką, barokową biżuterią [32]. Twierdzą oni, że silnie skontrastowane bodźce wzrokowe są bardziej atrakcyjne, gdyż prowadzą do przyjemnych doznań estetycznych, mózg bowiem jest wystawiony na "nasycone” i intensywne bodźce i zmuszony jest do optymalnego wysiłku - z kolei pobudzony „ruch neuronalny” i zaangażowanie w ten proces stanowi swoistą przyjemność i nagrodę dla perceptora (podobnie jak wysiłek fizyczny dla sportowca). Ramachandran tłumaczy, że detekcja kontrastu odbywa się już na bardzo wczesnych etapach przetwarzania i jest na tyle elementarna, że często zapomina się o tym, że może też przynosić nam przyjemność percepcyjną.

Analiza poniższych, oczywistych przykładów, podobnie jak i całego filmu, operującego formalnym (i semantycznym również) kontrastem, wydaje się w tym przypadku absolutnie niepotrzebna. Szara twarz Nadji zestawiona jest $\mathrm{z}$ iluminującym, gwiaździstym okręgiem na sklepowej witrynie; jednolity, czarny płaszcz - z nieokreślonymi, lecz tworzącymi zorganizowaną kształtem, mozaikową teksturę, czarno-białymi elementami wystawy, której nawet rama mieni się czarno-białymi punkcikami. Kadr drugi to, „jak marzenie” Lwa Kuleszowa[33] i ucieleśnienie kontrastu sensu largo. Biel, „miękkość” i gładź znicza o marmurowej teksturze wyeksponowane są z czarnej otchłani tła; ostre światło z prawej kontrowane jest majaczącym mrokiem strony lewej kadru. Ulotność i nieuchwytność tańczącego dymu, czerń, kruchość i szorstkość spalonego knota, żar, lekkość i skoczność płomienia - wydobywają się z nieruchomego, niezniszczalnego, wiecznością tchnącego, ciężaru kamienia.

Il. 16, 17. Kadry z filmu Nadja, reż. Michael Almereyda, 1994 rok

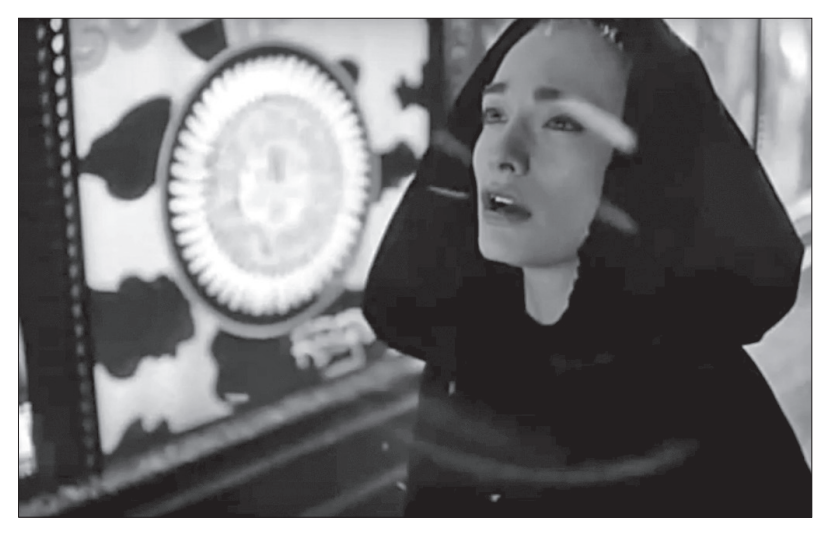

[32] Zob. V.S. Ramachandran, W. Hirstein, op.cit., s. 349 .

[33] Lew Kuleszow, rosyjski reżyser i teoretyk filmu, w roku 1917 rozpoczął prace nad percepcją kina;

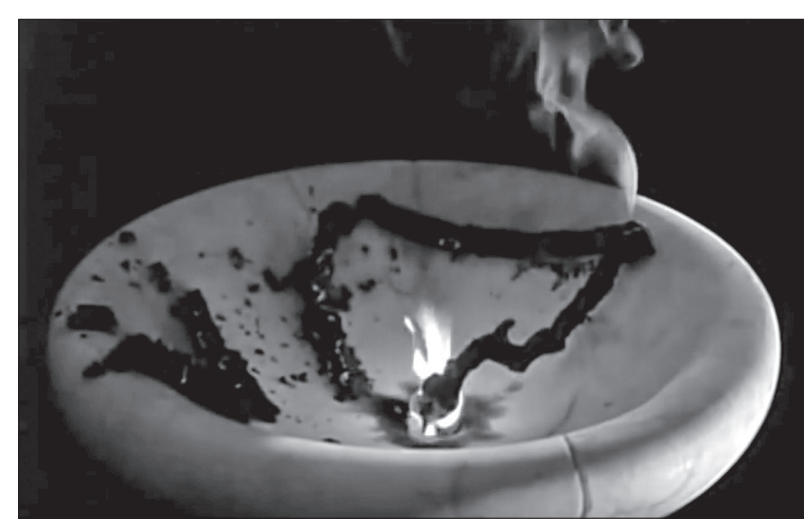

znany głównie jako ojciec radzieckiej szkoły montażu i odkrywca „efektu Kuleszowa”. Kuleszow był całkowicie świadomy priorytetowych problemów percepcji: według niego kadr powinien działać błyskawicznie 


\section{Rozwiązywanie problemów percepcyjnych}

To zasada, według której coś się wydaje atrakcyjne poprzez ukrycie części obiektu. Ramachandran przywołuje przykład atrakcyjności nagiej kobiety. Częściowe zakrycie atrybutów, nie tylko seksualnych, powoduje wzrost zainteresowania i spowodowane jest mózgowymi korelatami zaprogramowanymi do rozwiązywania zagadek percepcyjnych. Nasze mózgi bezustannie przetwarzają i rozszyfrowują niejednoznaczne dane, testują hipotezy, wyszukują i porównują informacje z tymi zapisanymi w pamięci oraz z oczekiwaniami. „Oczywisty” obraz całkowicie nagiej lub ubranej kobiety, gdzie prima facie obserwator ma podane wszystkie informacje „na tacy”, jeśli inne jej atrybuty nie generują wzmożonego zainteresowania, zostanie bardzo szybko zastąpiony przez perceptora na bodziec bardziej tajemniczy, złożony, niecodzienny, noszący w sobie wieloznaczność. „Tak więc lubimy częściowe przesłonięcie i lubimy rozwiązywanie łamigłówek, i lubujemy się w reakcji «Aha!»”[34]. Sygnał „Aha!” „przesyłany jest do limbicznych układów nagrody, które z kolei motywują poszukiwanie następnych, silniejszych «Aha!» tak długo, aż wreszcie wykrystalizuje się ostateczny obiekt czy scena" [35].

Dzieło Almereydy przesycone jest takimi „łamigłówkami”. W przykładowym kadrze pierwszym jawi się twarz jednego bohatera w szkle okularów drugiego, którego położenie i usytuowanie również stanowi zagadkę. Na drugiej ilustracji mamy do czynienia z eskalacją doznań formalnych oraz z rozpoznaniem elementów zarówno zawartych, jak i częściowo zakrytych lub niedostępnych w kadrze (przestrzeń pozakadrowa). Dodatkowo owa scena wnosi aspekt prawa grupowania, które aktywizuje wzmożoną uwagę na tym, co jest „wewnątrz” kroplówki (scena na schodach, dłoń trzymająca rewolwer, rozpływająca

Il. 18, 19. Kadry z filmu Nadja, reż. Michael Almereyda, 1994 rok się krew) oraz wymusza zestawianie tychże elementów w obiekty oraz rozpoznanie ich nieprzystawalności do całości obrazu.
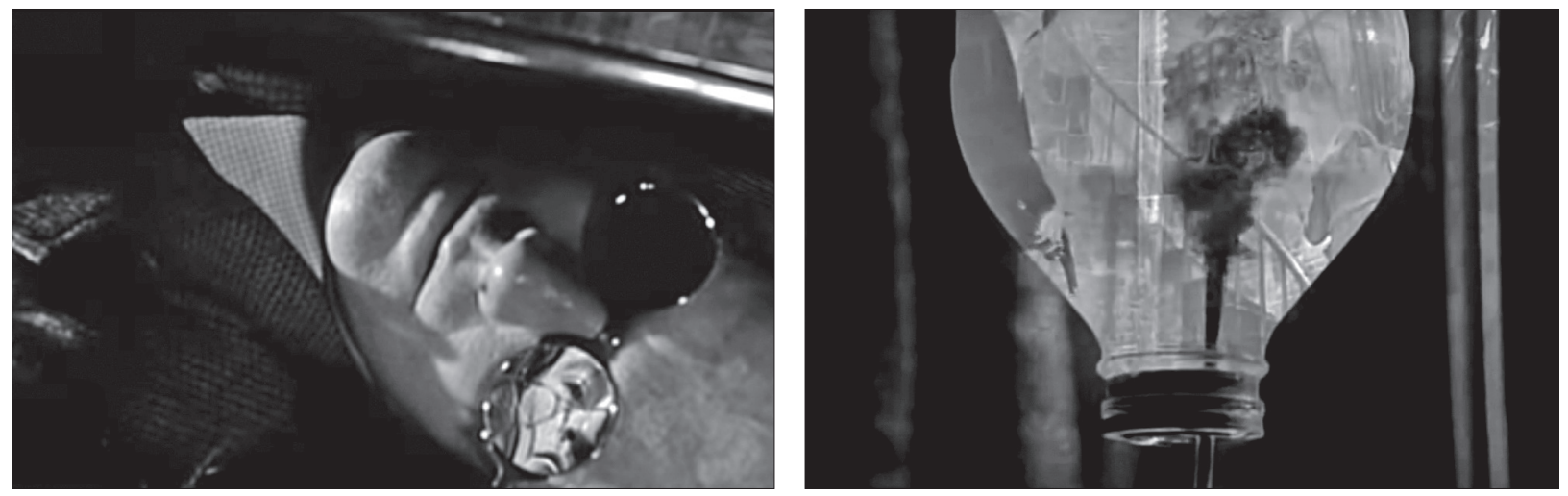

i w tym celu musi być specyficznie skomponowany. Kuleszow stosuje między innymi: a) neutralizację tła, b) eliminację zbędnych przedmiotów, c) istotne elementy eksponuje na czarnym aksamicie. Zob.
L. Kuleszow, Sztuka filmowa. Moje doświadczenia, przeł. W. Godzic, Kraków 1996.

[34] V.S. Ramachandran, W. Hirstein, op.cit., s. 247.

[35] Ibidem, s. 248. 


\section{Symetria}

Neurologiczna teoria doświadczenia estetycznego obejmuje także „odwieczne” zagadnienie symetrii. Ramachandran i Hirstein twierdzą, że symetria sprawia przyjemność estetyczną i jest rozpoznawana we wczesnych etapach procesu widzenia. Uważają oni, że symetria może służyć jako system wczesnego ostrzegania, ponieważ większość obiektów istotnych z biologicznego punktu widzenia - takich jak napastnik, ofiara, partner - ma wystrój symetryczny. Z ewolucyjnego punktu widzenia wiemy, że płód zarażony pasożytami jest narażony na asymetrię w budowie ciała, a to zmniejsza atrakcyjność partnera. Jednakże asymetria, nie będąc atrakcyjną w podświadomości na poziomie fizjologicznym i ewolucyjnym (imperatyw przekazywania zdrowych genów), stanowi również interesujący bodziec poznawczy. Ramachandran kilka lat później uzupełnił ową obserwację o atrakcyjność asymetrii, przywołując przykład urządzania mieszkania. Zauważa, że zasada atrakcyjności symetrii odnosi się do poszczególnych, jednostkowych i izolowanych obiektów (na przykład twarz), zaś asymetrii - do wielkich, złożonych scen: mózg nie lubi zbiegów okoliczności, a symetria w takowej scenie nie jest naturalna i traktowana jest jak kategoria niepokojącego zbiegu okoliczności[36].

Kadry ukazane na ilustracjach 20 i 21 są syntetyczną realizacją spójnego, satysfakcjonującego połączenia tychże dychotomii. Na pierwszy rzut oka są on skrajnie symetryczne na poziomie architektonicznym, jednak poszczególne elementy ową symetrię znoszą. Na ilustracji 20 światło padające $\mathrm{z}$ prawej strony tworzy asymetrię wertykalną, uwydatniając równocześnie asymetrię faktur, okien i drzwi. Przede wszystkim jednak oświetlony, skośny pręt na pierwszym planie łamie ową zasadę. Kadr drugi to gra światła w lewej części sceny oraz czerń ciężkiej materii obrazu, którym przeciwstawiony jest efemeryczny, szary cień ludzkiej sylwetki i i fragmentu łóżka z prawej strony. Aspekt asymetrii wnoszą również poszczególne twarze: wszystkie cztery (w tym portret na ścianie) zwrócone są w lewą stronę, a efekt potęguje fakt, że ułożone są pod tym samym kątem nachylenia.
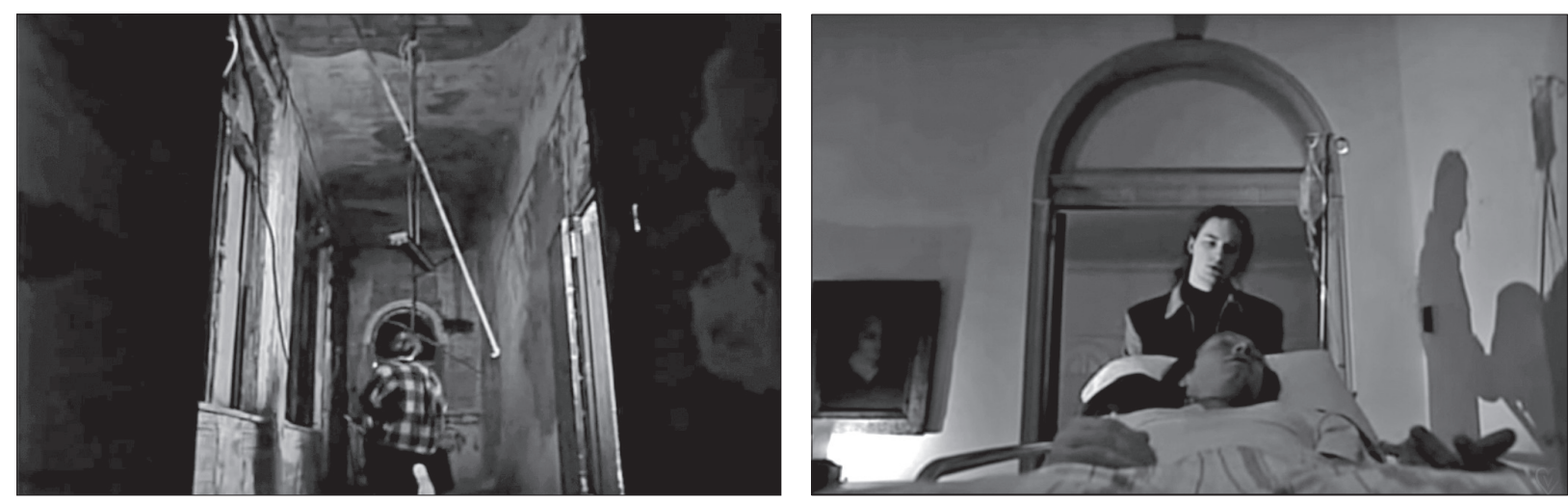

[36] Ibidem, s. 255. 


\section{Metafora}

Ostatnim z praw dotyczących doświadczenia estetycznego jest wprowadzanie do dzieła sztuki elementów metaforycznych[37], w szczególny sposób łączących dwa obiekty percepcyjne lub pojęcia, które z pozoru są do siebie zupełnie niepodobne. Uchwytywanie analogii jest jednym z podstawowych mechanizmów kognitywnych, które ułatwiają optymalne kodowanie świata. Połączenie dwóch pojęć lub perceptów niezwiązanych ze sobą stanowi wyzwanie dla aparatu poznawczego, a uchwycenie wspomnianej wyżej analogii i zdekodowanie intencjonalnej informacji przekazanej przez twórcę dzieła prowadzi do pobudzenia ośrodków w mózgu odpowiedzialnych za przyjemność związaną $\mathrm{z}$ dokonaniem takowego odkrycia. Owe uchwycenie jest osiągnięciem operacji umysłowych wyższego rzędu, dokonywanych na pojęciach (a nie tylko sensualnych obiektach), a co za nim idzie, efekt „Aha!” i związane z nim odczucie przyjemności oraz satysfakcji, szczególnie u specjalistów i koneserów sztuki czy literatury[38].

Scena ukazana na ilustracji 22 jest jedną z najbardziej „podręcznikowych”, realizujących zagadnienie metafory. Stanowi ona na poziomie wizualnym całkowite odwrócenie zasad percypowanego na co dzień świata, pojęciowo zaś - mistrzowskie ukazanie iluzji towarzyszącej egzystencji człowieka: wykorzystuje metaforę kliszy fotograficznej, "pozytyw-negatyw”. Nic nie jest tym co się wydaje. Wampiryczny brat Nadji, uzdrowiony i bezgranicznie szczęśliwy, wpada w objęcia swojej niewinnej ukochanej, nie wiedząc, że jej cielesność została przewłaszczona przez Nadję - kochającą go potajemnie miłością niesiostrzaną, egoistyczną i pragnącą nade wszystko zbawienia. Zło znowu wygrywa w odwiecznej, eschatologicznej grze.
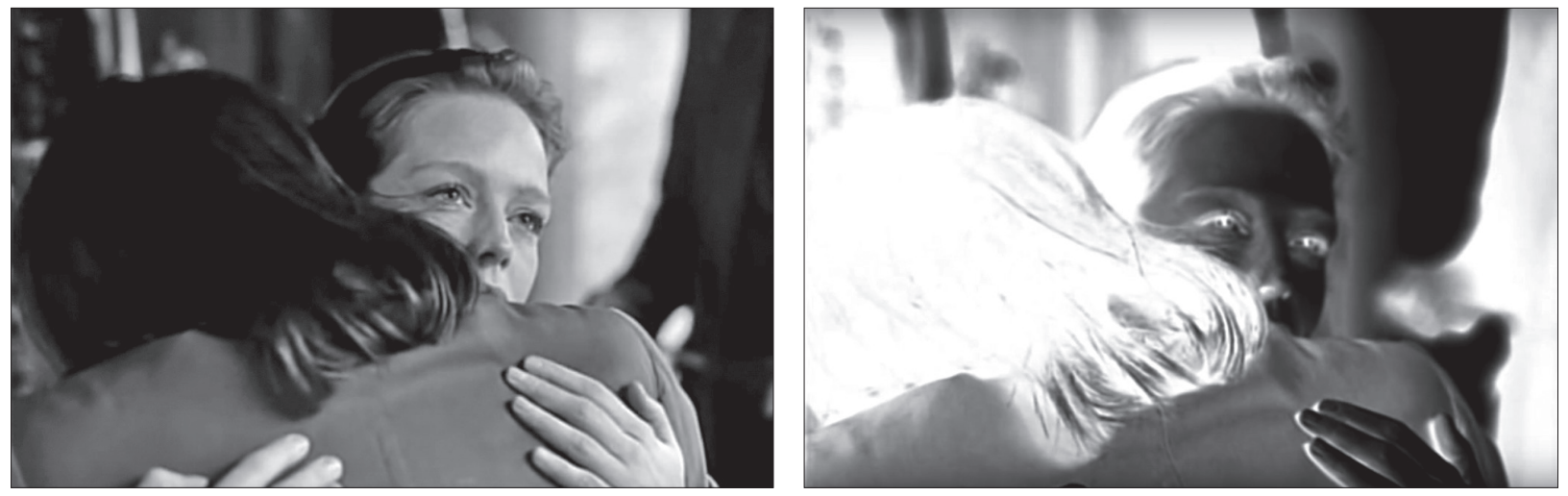

Il. 22, 23. Kadry z filmu Nadja, reż. Michael Almereyda, 1994 rok
Jednakże dzieło Michaela Almereydy wykracza daleko poza powyższe postulaty, wykorzystuje fenomen i specyfikę dzieła filmowego
[37] V.S. Ramachandran, W. Hirstein, op.cit., s. 355. [38] Jak również naukowców. Szczególnie i wyjątkowo trudne zadania poznawcze zwieńczone sukcesem, to Archimedesowska „eureka!”, olśnienie, graniczące z ekstazą, które to doznania mentalne pod względem neurobiologicznym uwalniają analogiczne neuroprzekaźniki w mózgu, jak w przypadku satysfakcji seksualnej. 
jako czasoprzestrzennej kreacji, nieosiągalnej przez dzieło na przykład malarskie. Nad warstwą formalną została nadbudowana zasada przesunięcia szczytowego w warstwie narracji. Fabułę filmu tworzą dwa skrajne światy - intencjonalnie lub nie - dodatkowo wprowadzając pierwiastek akulturacji. Te światy to prosty, konsumpcyjny i powierzchowny świat duszy amerykańskiej oraz pełen skrajności i sprzeczności, skomplikowany, pędzący ku metafizyce, głęboki duch Słowian. Dualizm ten, w warstwie wizualnej urzeczywistniony za pomocą kontrastu i przesunięcia szczytowego, widoczny jest na poniższych kadrach. Rumunka - czujna, wyrazista, esencjonalna w spojrzeniu i wyrazie twarzy, spowita w czarny płaszcz z narzuconym na głowę kapturem przeciwstawiona jest znudzonej, „szarej” dziewczynie boksera, ubranej w sportowe ubranie. Amerykanka beznamiętnie, z pustym spojrzeniem i jakby bezcelowo sączy piwo, Nadja, pełna namiętności - jednym ruchem wypija kieliszek wódki.

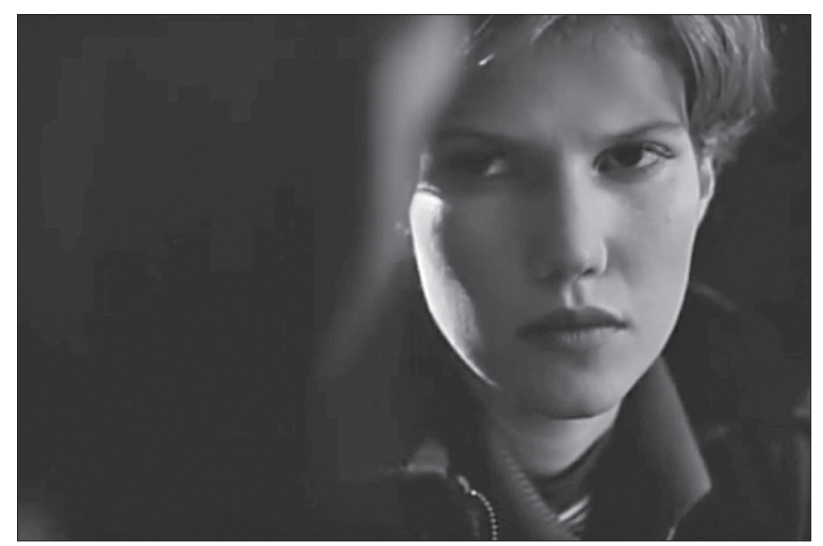

Również sceny rozgrywające się w Ameryce i w Rumunii nacechowane są ową opozycją formalną, nie tylko w warstwie nasycenia kontrastu, ale też samej scenerii. Na ilustracjach 26 i 27 świat banalnej pospolitości bokserskiej sali treningowej stoi w superpozycji do wyrafinowanego, niesamowitością tchnącego, „soczystego” artyzmu ducha Karpat.

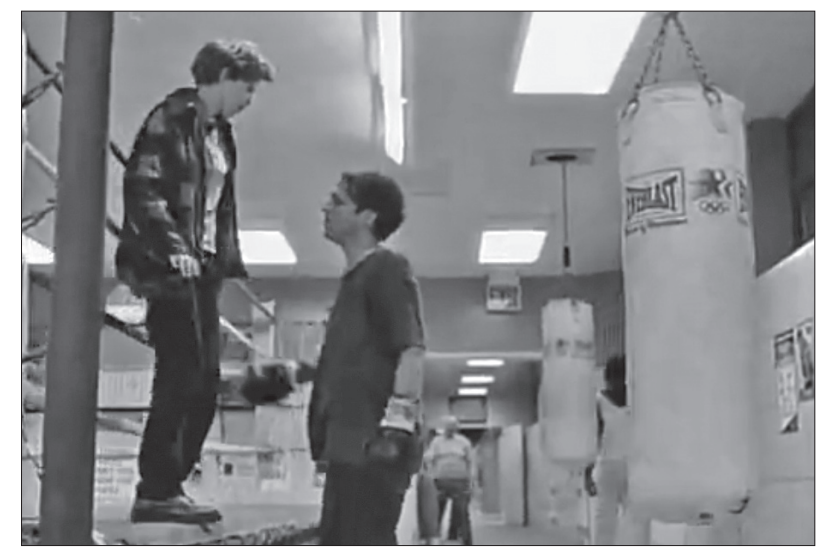

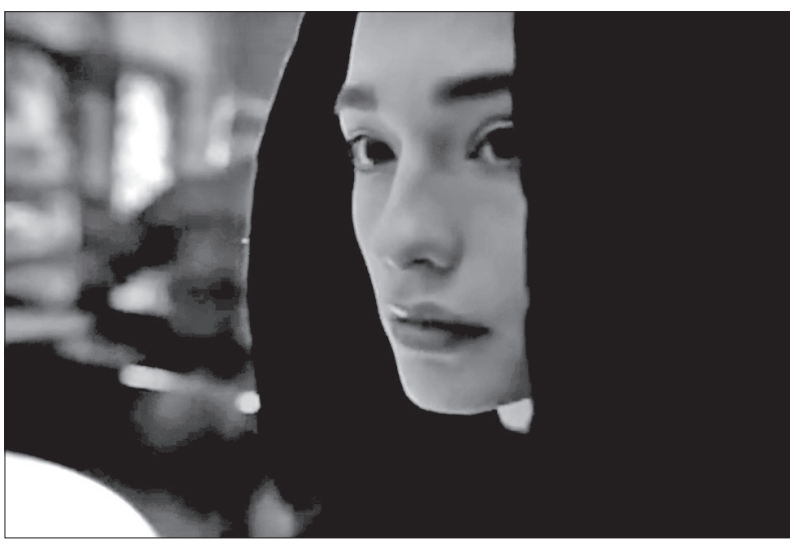

Il. 24, 25. Kadry z filmu Nadja, reż. Michael Almereyda, 1994 rok

Il. 26, 27. Kadry z filmu Nadja, reż. Michael Almereyda, 1994 rok

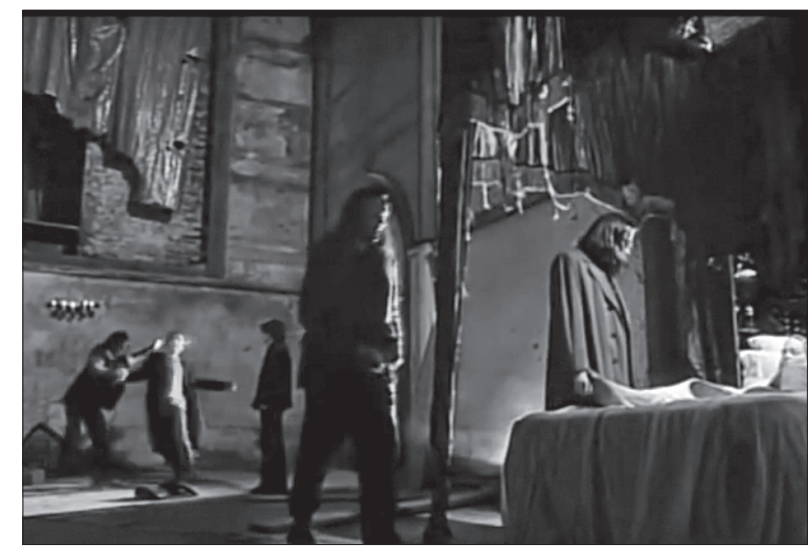


Zakończenie

B I B L I O G R A F I A
W powyższej analizie pojedynczego dzieła sztuki filmowej Nadji (1994) Michaela Almereydy - starałam się wykazać, że prawa neuroestetyki rządzą również sztukami złożonymi, takimi jak na przykład właśnie film. Zanim bowiem damy się ponieść typowo ludzkim, namiętnym potrzebom obcowania ze sztuką, wyższym procesom poznawczym, interpretacyjnym i refleksyjnym oraz towarzyszącym im uczuciom zachwytu, uniesienia lub dezaprobaty - w pierwotnych, sensualnych procesach percepcji, rządzą nami ukryte i uniwersalne mechanizmy ewolucyjnego imperatywu oraz nieuświadomionej, „,zwierzęcej” ciekawości świata.

Niezwykłe oddziaływanie sztuki na człowieka pozostaje od wieków nieodgadnioną tajemnicą. Koncepcje badaczy zajmujących się badaniem procesów neurobiologicznych, jak Semir Zeki, Margaret Livingstone czy Vilayanur S. Ramachandran, pozwalają bardziej naukowo spojrzeć na ulotną naturę artyzmu i zbudować neurobiologiczną podstawę do definiowania dzieł sztuki i towarzyszącym im procesów poznawczych i emocjonalnych zarówno twórcy, jak i odbiorcy, lecz, jak pisze V.S. Ramachandran, redukcjonistyczne podejście do estetyki w żadnej mierze nie prowadzi do umniejszenia wyrazu wielkich dzieł sztuki. Wręcz przeciwnie, może nam nawet pomagać pełniej pojąć tę ich nieuchwytną od czasów Platona i Pseudo-Dionizego Areopagity, wyjątkową i prawdziwą wartość.

$\mathrm{Z}$ uwagi na rodzaj niniejszej pracy analiza kadrów filmu ma charakter jedynie poglądowy. W zasadzie każdy kadr z osobna, każda scena i ujęcie zasługują na szczegółowe zgłębienie i interpretację. Jednakże zastosowane w analizie obrazu Almereydy narzędzie wskazuje, że wykorzystanie powyższych praw zawiera w sobie niezwykły potencjał badawczy oraz może stanowić ciekawy element warsztatu nie tylko dla filmoznawców, ale również rodzaj gry lub wyzwanie dla nieeksperckiego konesera sztuki jako takiej.

Autorka składa podziękowania Jackowi Skoczylasowi z SOLOPAN Sp. z o.o. za możliwość wykorzystania materiałów filmowych.

Arnheim R., Film jako sztuka, przeł. W. Wertenstein, Warszawa 1961

Arnheim R., Sztuka i percepcja wzrokowa. Psychologia twórczego oka, przeł. J. Mach, Gdańsk 2004

Baranowski P., Przybysz P., Neuroestetyka wieloznaczności. Percepcja vs. interpretacja w sztuce decentryzmu, [w:] Filozof w krainie umysłów, Poznań 2018

Burke E., A Philosophical Enquiry into the Origin of Our Ideas of the Sublime and the Beautiful, Harmondsworth 1998

Francuz P., Imagia. W kierunku neurokognitywnej teorii obrazu, Lublin 2013

Helman A., Ostaszewski J., Historia myśli filmowej, Gdańsk 2007

Ishizu T., Zeki S., W stronę neurobiologicznej teorii piękna, „Via Mentis” 2012, 1 (1)

Jaśkowski P., Neuronauka poznawcza, Warszawa 2009 
Kawabata H., Zeki, S., Neural correlates of beauty, "Journal of Neurophysiology" 2004, 91(4), s. 1699-1705

Kuleszow L., Sztuka filmowa. Moje doświadczenia, przeł. W. Godzic, Kraków 1996

Livingstone M., Vision and Art: The biology of seeing, New York 2002

Markiewicz P., Przybysz P., Neuroestetyka. Przeglad zagadnień i kierunków badań, [w:] Na ścieżkach neuronauk, red. P. Francuz, Lublin 2010

Maruszewski T., Psychologia poznania, Gdańsk 2001

Przybysz P., O naturze emocji towarzyszacych odbiorowi sztuki. Dynamiczne i sytuacyjne podejście do emocji estetycznych, „The Polish Journal of Aesthetics” 2017, t. 46, nr 3

Przybysz P., O uchwytywaniu piękna. Rola deformacji estetycznych $w$ tworzeniu i percepcji dzieła sztuki w ujęciu neuroestetyki, [w:] Mózg i jego umysty. Studia z kognitywistyki i filozofii umysłu, t. 2, red. W. Dziarnowska, A. Klawiter, Poznań 2006

Ramachandran V.S., Neuronauka o podstawach człowieczeństwa. O czym mówi mózg, przeł. A. Binder, M. Binder, E. Józefowicz, Warszawa 2012

Ramachandran V.S., Hirstein W., Nauka wobec zagadnienia sztuki. Neurologiczna teoria doświadczenia estetycznego, przeł. P. Przybysz, [w:] Mózg i jego umysty. Studia z kognitywistyki i filozofi umystu, t. 2, red. W. Dziarnowska, A. Klawiter, Poznań 2006

Tan E., Emocje a sztuka i humanistyka, [w:] Psychologia emocji, red. M. Lewis, J.M. Haviland-Jones, Gdańsk 2005

Wilson E.O., Konsiliencja. Jedność wiedzy, przeł. J. Mikos, Poznań 2002

Zeki S., Blaski i cienie pracy mózgu. O miłości, sztuce i pogoni za szczęściem, przeł. A. i M. Binderowie, Warszawa 2012

Zeki S., Visual art and the visual brain, „The Woodhull Lecture” 1995 